\title{
Simulation for Integrated Systems of Typical Coal-to-liquids Processes and Waste Energy Exploitation Based on Different Gasification Processes
}

\author{
Ge-wen $\mathrm{YU}^{\mathrm{a}, *}$, Xiao-li $\mathrm{YANG}^{\mathrm{b}}$ and Yan-ming $\mathrm{WANG}^{\mathrm{c}}$ \\ Chemistry and Chemical Engineering School, Inner Mongolia University \\ of Science \& Technology, Baotou 014010, PR China \\ a yugw0214@163.com, b1627412807@qq.com, ${ }^{\mathrm{c}}$ 2038634385@qq.com
}

\begin{abstract}
Integrated systems of FT liquids processes and waste energy utilization based on Shell, GSP and GE gasification are designed and simulated. The results show that under the condition of $1000 \mathrm{t} / \mathrm{hr}$ coal feedstock, the yields of the liquids, including diesel, naphtha and LPG, are 205.2t/hr, 73.2t/hr and $40.1 \mathrm{t} / \mathrm{hr}$, respectively based on shell; $205.1 \mathrm{t} / \mathrm{hr}, 73.2 \mathrm{t} / \mathrm{hr}$ and $40.1 \mathrm{t} / \mathrm{hr}$, respectively based on GSP; $183.8 \mathrm{t} / \mathrm{hr}, 65.6 \mathrm{t} / \mathrm{hr}$ and $35.9 \mathrm{t} / \mathrm{hr}$ respectively based on GE. However, the electricity generation equivalent to about $2 \%$ of coal thermal value cannot meet the power needs of the three systems. Based on LHV, the highest system thermal efficiency of $47.7 \%$ comes from the system based on Shell. The lowest system thermal efficiency, resulting from the system based on GE, has decreased $7.1 \%$ compared with that of the system based Shell. The proportion of carbon capture to the total carbon entering the systems is $\mathbf{5 8 . 7 \%}$ (for the system based on Shell), $\mathbf{5 8 . 6 \%}$ (for the system based on GSP) and $59.5 \%$ (for the system based on GE), respectively.
\end{abstract}

Keywords - polygeneration; gasification; syngas; WGS; FT synthesis; combined cycle

\section{INTRODUCTION}

Considering the higher energy consumption and environmental pollution caused by fossil energy industries has become bottlenecks for the sustainable economic development, the exploration of efficient and clean utilization has become more and more significant. From a perspective of feasibility option, polygeneration systems based on gasification may present an opportunity to overcome energy and environment problems caused by conventional coal technologies [1-4]. The concepts of polygeneration and energy integration has been discussed and various examples of polygeneration systems has been investigated. The result is evident that polygeneration systems which include appropriate process integration significantly increase the efficient utilization of natural resources [5]. Some researchers has designed and simulated polygeneration of alternative fuel and electricity from coal and natural gas. In this study, two related processes were compared with a comprehensive sustainability assessment. Scores were given to each process with regard to their performance in four categories: economic, safety, environmental and efficiency. The study has proved the sustainability assessment methodology is quite convenient in the selection or modification of processes [6]. In a research performances of $\mathrm{H}_{2}$ /electricity co-production systems with $\mathrm{CO}_{2}$ capture are compared with those of the systems venting $\mathrm{CO}_{2}$. The result has been obtained that a loss of $6 \%-8 \%$ points of electricity conversion is entailed when capturing $\mathrm{CO}_{2}$ as an alternative to venting it. And $\mathrm{CO}_{2}$ capture for $\mathrm{H}_{2}$ production causes an energy loss about $2 \%$ points of export electricity [7]. Recently, many researchers pay their close attention to the polygenerations feeding biomass. A study presents preliminary feasibility and performance estimation using thermodynamic model in Aspen Plus for agricultural waste based polygeneration with electricity, refrigeration, utility heat and ethanol as outputs. Results have shown that such polygeneration is highly promising as decentralized efficient option, specifically for rural people [8]. Polygeneration has been reviewed about the technical feasibility and economics of biomass integrated gasification and FT synthesis processes in general. The research suggests that the aim should be the development of large-scale (pressurized) biomass gasification-based systems and special attention must be given to the gas cleaning section [9]. Some researchers have investigated new possibilities and synergy effects for an oxy-fuel fired polygeneration scheme (transportation fuel and electricity) with carbon capture and co-firing of biomass. They conclude that the proposed oxygen lean combustion process constitutes a way to improve the oxy-fuel carbon capture processes with an efficient production of dimethyl ether (DME) in the polygeneration process [10].

Nowadays some countries are abundant in coal but are short of domestic oil and natural gas resources. And, compared with biomass, coal has larger energy density and related process is mature. So the people are likely to turn to coal as a basis for providing synthetic liquid fuels for transportation and other applications [11]. FT synthesis can be applied to convert the syngas derived from various nonpetroleum resources, such as coal, natural gas, biomass or other carbon containing materials to liquid fuels. FT liquids are beneficial to environmental protection because of almost free of sulfur and aromatics. FT synthesis technology has been run successfully on commercial scale $[12,13]$. The growing market for this technology also drives further technological development of FT related processes. Some recent studies focus on new types of cheap Fe-based catalysts and slurry reactor $[14,15]$. These studies have further improved FT synthesis technology. Potential coproducts may also be realized by utilizing material and 
energy that is not directly associated with FT hydrocarbons. For example, waste heat may be converted to electrical power for sale.

Pressured entrained flow gasifiers have higher gasification efficiency (for example, Shell and GSP, 80\%$83 \%$, GE, over $70 \%$ ) and have been widely served for single chemical industries or single electricity generation $[16,17]$. However, how to judge which gasification process is optimum depends on what kind of production they manufacture.

For example, GSP gasification is proved to use very well for Coal to Ammonia [18]. Some studies give advice that Shell gasification process is optimum to the chemical synthesis [19]. Some reviews recommend that GE gasifier is more suitable for Coal to Liquids than other gasification processes $[20,21]$. Furthermore, how gasification processes affect the polygeneration system performance is not very clear. A previous research, which studies the polygeneration systems of FT liquids-power based on Shell gasification process, has shown that system of series connection type has higher energy efficiency than those of parallel connection type [22]. This aim of paper is to evaluate performances, energy efficiency and $\mathrm{CO}_{2}$ capture of polygeneration systems based on different gasification processes.

The main research objectives are:

To explore the technical feasibility of polygeneration systems of FT liquids and power in general.

To identify the most promising system configurations based on different gasification processes.

a. The detailed material and energy balance calculation for the overall systems.

b. The transition and distribution of coal energy in subsystems such as gasification process, water-gas shift (WGS) and purification process, FT synthesis and upgrading process, and combined cycle process.

To explain the decrease of $\mathrm{CO}_{2}$ vent of different cases.

$\bar{A}$ bove purposes will be achieved through three cases.

Case 1: the integrated system of FT liquids-electricity based on Shell gasification process.

Case 2: the integrated system of FT liquids- electricity based on GSP gasification process.

Case 3: the integrated system of FT liquids-electricity based on GE gasification process.

\section{DESIGN}

Process configurations for the systems are based on the commercially available technologies. These configurations include: air separation unit (ASU), entrained flow gasification (Shell, GSP and GE technology), WGS process, low temperature physical absorption (Rectisol process), slurry FT synthesis, syncrude upgrading process, pressure swing adsorption (PSA) for $\mathrm{H}_{2}$ separation and combined cycle for electricity generation. Fig. 1 shows the flow schemes for the three cases.

\section{MethodolOGY}

In this paper, the integrated systems based on three gasification processes are designed and simulated and their mass conversion and energy transition are analyzed. All the cases are evaluated by Excel-Aspen Plus models, which take trade-off between flexibility and accuracy into consideration. Generally, the detailed processes are simulated by Aspen Plus to get key parameters and the simple input-outputs are calculated by Excel models.

RGibbs model, which performs chemical and phase equilibrium by Gibbs energy minimization, is used to simulate gasifier. Coal is indirectly simulated by Aspen. An efficient solution is that the reaction is divided into two steps: Firstly the coal is broken up into the components including $\mathrm{C}$, $\mathrm{H}_{2}, \mathrm{O}_{2}, \mathrm{~N}_{2}, \mathrm{~S}, \mathrm{H}_{2} \mathrm{O}$ and ash. And then they interact to reach chemical equilibrium [23]. Defined components of raw syngas include: $\mathrm{CO}, \mathrm{H}_{2}, \mathrm{CO}_{2}, \mathrm{H}_{2} \mathrm{O}, \mathrm{CH}_{4}, \mathrm{O}_{2}, \mathrm{~N}_{2}, \mathrm{Ar}, \mathrm{H}_{2} \mathrm{~S}$, $\mathrm{COS}$, and else trace components $\left(\mathrm{NH}_{3}, \mathrm{HCN}\right.$, S, et al.). A Requil model is applied for WGS reactor is modeled to simulate chemical equilibrium and phase equilibrium. Sulfur-tolerant shift which directly proceed after the gasification and washing can reasonably exploit the utility of the gasification heat. At the same time, the saturated syngas reacting under a higher temperature can reduce the consumption of the injected steam because it contains more water vapor and therefore a reasonable flow matching can be obtained.

Net energy efficiency ( $E F F$ ) and carbon capture ratio $(\eta c)$ are defined:

$$
\begin{gathered}
E F F=\frac{\sum \varphi_{\text {useful products }}}{\sum \varphi_{\text {feedstock }}+\sum \varphi_{\text {utilities }}} \\
\eta_{c}=\frac{M_{c c}}{M_{t c}} \times 100 \%
\end{gathered}
$$

Formula (1): The units of all $\phi i$ are converted to tce (ton coal equivalent) units. In numerator the term $\sum \varphi_{\text {useful products }}$ includes synfuel products, sulfur element and net electricity output, which is the generated electricity subtracts the consumed electricity. In denominator $\sum \varphi_{\text {feedstock }}$ is input coal and $\sum \varphi_{\text {utilities }}$ includes consumed electricity, steams and water.

Formula (2): Mcc is carbon captured (t/hr). Mtc is total carbon in the whole system (t/hr).

\section{TECHNOLOGY DESCRIPTION AND SUB-SYSTEM CALCULATION}

\section{A. Coal Preparation}

The properties of the coal (bituminous) used for the study is shown in table 1 . 
TABLE I. PROPERTIES OF COAL

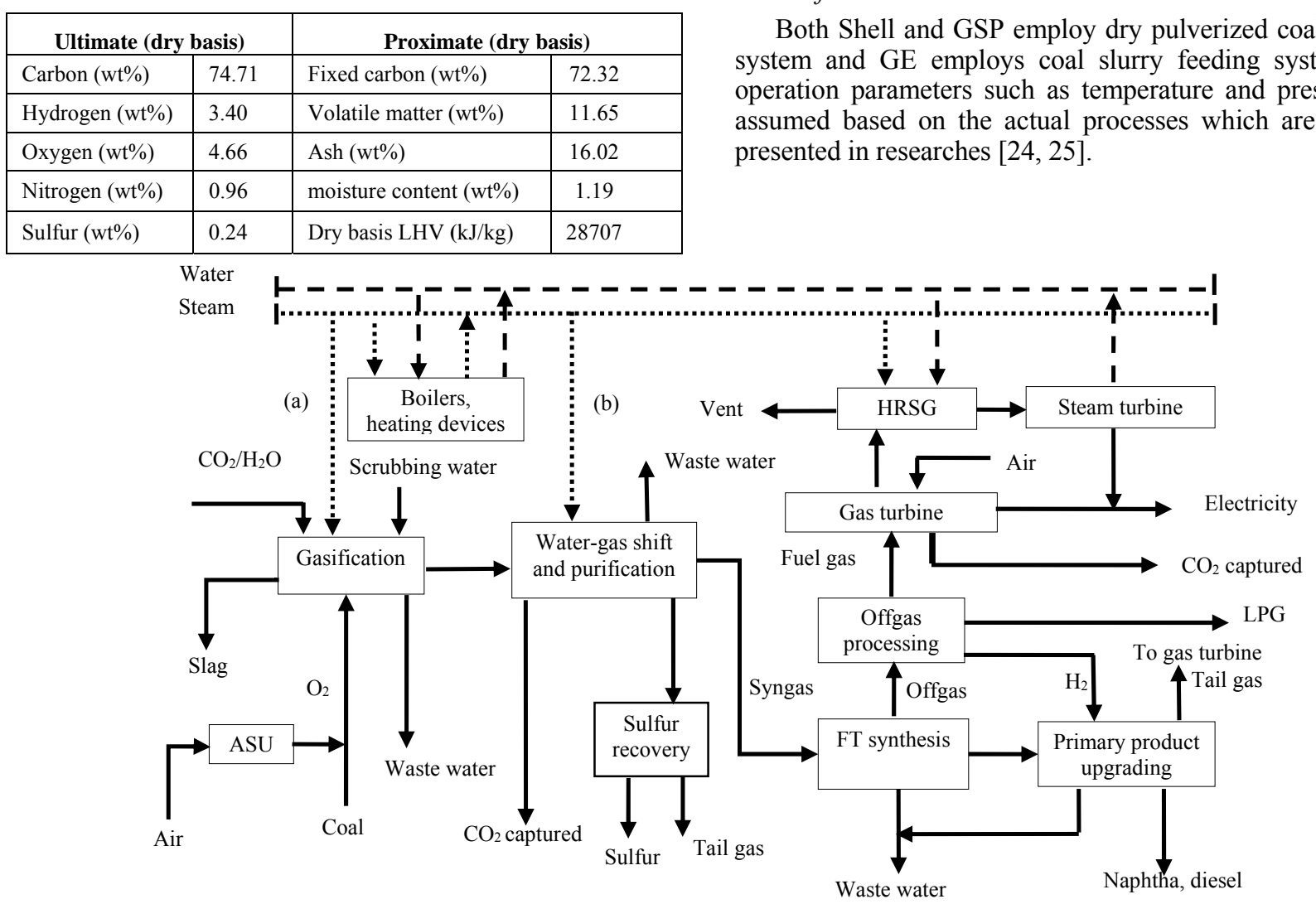

\section{B. Gasification Process}

Both Shell and GSP employ dry pulverized coal feeding

Figure 1. The systems of FT liquids-electricity based on different gasification.

Note: (a) Steam for Shell and GSP gasification. (b) Steam for WGS based on Shell's syngas.

\section{1) Shell gasification process}

Mixture of pulverized coal (with water no more than 2\% by weight), additive limestone, pure oxygen and steam are fed into gasifier. The operating pressure and temperature are 4.0MPa and $1400^{\circ} \mathrm{C}$. Liquid slag flows down the wall and discharge from the bottom, raw syngas lets out from the top and is quenched by cycled cooled-gas to $900^{\circ} \mathrm{C}$ to avoid sticking of fly ash in boiler. The raw syngas is cooled down to $350^{\circ} \mathrm{C}$ in the boiler and enters wet scrubbing system (washing tower), where a majority of fly ash and watersoluble contaminants (primarily $\mathrm{HCN}, \mathrm{NH}_{3}$, and chlorides) are removed. In the gasification unit, $5.2 \mathrm{MPa}$ steam is generated, partial of which is used for WGS unit.

2) GSP gasification process

Similar to Shell technology, GSP process operates under the condition of $4.0 \mathrm{MPa}, 1400^{\circ} \mathrm{C}-1600^{\circ} \mathrm{C}$. Coal powder is also fed into the gasifier using $\mathrm{CO}_{2}$ as the carrier. The one of differences between the two processes is GSP adopts chilled water to cool the hot syngas and Shell adopts cycled cooledgas. The chilled water is injected into a venturi to make the hot syngas temperature decrease to about $210{ }^{\circ} \mathrm{C}$. At the same time, the water vapor is saturated in the raw syngas. And then the saturated syngas enters the washing tower scrubber to get rid of the remaining fly ash and the temperature drops to about $200{ }^{\circ} \mathrm{C}$.

3) GE gasification process

For GE gasifier, the coal slurry and oxygen are injected from the top of the gasifier. The operating temperature and pressure are $1360^{\circ} \mathrm{C}$ and $5.0 \mathrm{MPa}$. The hot raw syngas is firstly cooled down to $720^{\circ} \mathrm{C}$ in a radiant cooler where $4.0 \mathrm{MPa}$ steam is generated, and then enters the water scrubber. By carefully adjusting the washing water amount, the syngas temperature maintains about $200^{\circ} \mathrm{C}$ to meet the requirement of the starting temperature of the WGS reaction. The slag settles in the quench water at the bottom of the radiant cooler and is removed by the slag removal system. All particulate and most water-soluble contaminant are removed in the water scrubber just like Shell process.

RGibbs models are employed to simulate the gasifiers for Aspen Plus. The results of simulation are shown in Table 2. 
TABLE II . THE RESULTS COMPARISON OF COAL GASIFICATION PROCESSES

\begin{tabular}{|c|c|c|c|}
\hline Components and parameter & Shell & GSP & GE \\
\hline $\mathrm{CO}(\%)$ & 69 & 69.03 & 42.4 \\
\hline $\mathrm{H}_{2}(\%)$ & 22.88 & 22.89 & 25.18 \\
\hline $\mathrm{CO}_{2}(\%)$ & 3.43 & 3.43 & 13.71 \\
\hline $\mathrm{H}_{2} \mathrm{O}(\%)$ & 3.5 & 3.5 & 16.87 \\
\hline $\mathrm{CH}_{4}(\%)$ & 0.05 & 0.04 & 0.22 \\
\hline $\mathrm{N}_{2}(\%)$ & 0.37 & 0.37 & 0.37 \\
\hline $\mathrm{H}_{2} \mathrm{~S}+\mathrm{COS}(\%)$ & 0.08 & 0.08 & 0.07 \\
\hline Else (\%) & 0.69 & 0.66 & 1.18 \\
\hline Average molecular weight & 22.2 & 22.1 & 21.78 \\
\hline mole flow rate (kmol/hr) & 90343 & 90349 & 108838 \\
\hline Temperature ( $\left.{ }^{\circ} \mathrm{C}\right)$ & 1400 & 1400 & 1360 \\
\hline $\mathrm{Pressure}(\mathrm{MPa})$ & 4 & 4 & 5 \\
\hline $\mathrm{O}_{2} /$ coal $(\mathrm{kg} / 1000 \mathrm{~kg})$ & 835.5 & 835.6 & 958.5 \\
\hline $\mathrm{Steam} /$ coal $(\mathrm{kg} / 1000 \mathrm{~kg})$ & 120 & 120 & - \\
\hline $\mathrm{CO}_{2} / \mathrm{coal}(\mathrm{kg} / 1000 \mathrm{~kg})$ & 157.2 & 157.2 & - \\
\hline $\mathrm{Coal}$ slurry (wt\%) & - & - & 65.7 \\
\hline Steam output (t/hr) & 1244.7 & - & 1484.4 \\
\hline $\mathrm{Cool}_{\text {gas efficiency }(\%)}$ & 80.1 & 80 & 70.1 \\
\hline
\end{tabular}

Shell and GSP gasifiers adopt the same operating temperature $\left(1400^{\circ} \mathrm{C}\right)$ and pressure $(4.0 \mathrm{MPa})$. The heat loss of them is assumed equal because of the use of water-cool wall and the same quantity of feedstock including coal, oxygen and steam. These factors cause similar results including gas components, mole flow rate and higher cold gas efficiency. The heat loss of GE gasifier is assumed half that of Shell and GSP gasifiers because the inner wall of GE gasifier is pasted with fire-resistant bricks whose thermal conductivity is higher than that of Shell and GSP gasifier's water-membrane wall. The results of the simulation show that, comparing GE gasifier with Shell gasifier, the former generates more $\mathrm{CO}_{2}$ and $\mathrm{H}_{2}$ as well as less $\mathrm{CO}$ in the syngas components. This is because partial pressure of the water vapor is high enough to promote WGS reaction by using coal slurry feed in GE gasifier. On the other hand, coal slurry gasification needs to consume extra calories, thereby the oxygen consumption increases and more carbon is changed into carbon dioxide. Due to water chilling, the syngas from GSP and GE gasifier contains saturated water vapor, which is beneficial to WGS process.

\section{Water-gas Shift Process}

WGS process is applied to increase the $\mathrm{H}_{2} / \mathrm{CO}$ ratio to meet the need of FT synthesis. The main reaction in WGS reactor is:

$\mathrm{CO}+\mathrm{H}_{2} \mathrm{O}=\mathrm{CO}_{2}+\mathrm{H}_{2} \quad \Delta \mathrm{H}=-41.09 \mathrm{~kJ} / \mathrm{mol}(298.15 \mathrm{~K})$.

Different catalysts have been developed for WGS reactions, including $\mathrm{Fe}-\mathrm{Cr}$ based high temperature catalysts, $\mathrm{Cu}-\mathrm{Zn}-\mathrm{Al}$ based low temperature catalysts and Co-Mo based sulfur-tolerant catalysts [26, 27]. Co-Mo catalyst can be used in a wide range of temperature. Moreover, the organic sulfur compounds can be hydrolyzed on Co-Mo catalyst and become easier to be removed from the raw syngas [28]. So Co-Mo catalyst is selected for WGS reaction.

Multistage adiabatic fixed bed reactors are employed in WGS section. In Aspen Plus, two REquil model series run to realize appropriate $\mathrm{H}_{2} / \mathrm{CO}$ ratio about 1.5 for FT synthesis.
To meet the requirement of catalyst, the temperature is controlled within $200^{\circ} \mathrm{C} \sim 455^{\circ} \mathrm{C}$ and the pressure is $3.5 \mathrm{MPa}$. The extra water vapor need to be injected because there is no enough water vapor amount satisfy WGS reaction in the Shell's syngas. Saturated vapor (5.2MPa) produced in Shell gasification process can be used to supplement the shortage of water vapor from the perspective of the system optimization. Calculation shows molar ratio of the injected water vapor to the syngas is $0.15: 1$, while GSP and GE synthesis gas contains enough water vapor and there is no need to add extra water vapor.

A series of heat exchangers and boilers are connected to control reaction temperature and generate the saturated steams of $3.5 \mathrm{MPa}$ and $0.6 \mathrm{Mpa}$. The shifted syngas is finally cooled down to $15^{\circ} \mathrm{C}$, and then is sent to acid gas removal process.

\section{Acid Gas Removal and Sulfur Recovery}

Both Rectisol and Selexol are advanced acid gas removing process. However, Rectisol process has more advantages such as less utilities consumption, less operation cost and investment [29]. So it is employed here to remove acid gas including $\mathrm{H}_{2} \mathrm{~S}$, COS, and $\mathrm{CO}_{2}$ before the shifted syngas goes into FT synthesis reactors and gas turbines [30]. In order to simplify the calculation, it is assumed that $100 \%$ of sulfides are removed. Since Fe-based catalysts require the content of $\mathrm{CO}_{2}$ in the syngas is no more than $1 \%(\mathrm{~mol} \%)$ to ensure well-balanced FT synthesis reaction, the rest of $\mathrm{CO}_{2}$ must be removed. The previous research showed the high partial pressure of $\mathrm{CO}_{2}$ enhanced the reverse reaction rate of the WGS and decreased the $\mathrm{CO}_{2}$ formation rate [31]. The $\mathrm{CO}_{2}$ selectivity decreased rapidly when a large amount of $\mathrm{CO}_{2}$ is in the feed gas, while the hydrocarbon formation rate decreased slightly and the overall oxygenate formation rate decreased. Absorber for $\mathrm{CO}_{2}$ sequestration operates under $3.0 \mathrm{MPa}$ and cryogen of $0.1 \mathrm{MJ} / \mathrm{kg}$ syngas is necessary to maintain the methanol temperature under $-55^{\circ} \mathrm{C}[32]$.

\section{E. Fischer-Tropsch Synthesis}

Fischer-Tropsch technology can be briefly defined as the means used to convert syngas containing hydrogen and carbon monoxide to hydrocarbon products. From 1980's, slurry phase reactors was used to ultimately produce mainly diesel with naphtha as a significant co-product by using a scheme in which the reactor wax is hydrocracked [33]. $\mathrm{H}_{2} / \mathrm{CO}$ ratio of the feed gas of FT synthesis process varies in a wide range. Dry reported the $\mathrm{H}_{2} / \mathrm{CO}$ ratio (by moles) into slurry reactor for iron catalyst was 1.7 [34]. But in other studies, the $\mathrm{H}_{2} / \mathrm{CO}$ ratio seemed in favor of $0.67[35,36]$. And then, a series of iron based catalysts were improved and ran at the mole ratio from 1.0 to 1.7 in the pilot plant test. The pilot test results showed that the iron based catalysts which acclimatized to the radio of 1.5 is favorable, so in this paper, $\mathrm{H}_{2} / \mathrm{CO}$ ratio of the shifted syngas is assumed to be 1.5. Based on the researches of catalysts performance in FT synthesis, Fe based catalyst and slurry reactors are employed for this study [37, 38]. In FT synthesis, $\mathrm{CO}$ and $\mathrm{H}_{2}$ react exothermically in the presence of the catalysts to produce hydrocarbons, ranging from methane to high molecular 
weight wax ( $>\mathrm{Cn} 42)$. The offgas composed of hydrocarbons, $\mathrm{CO}_{2}, \mathrm{H}_{2} \mathrm{O}$, unreacted $\mathrm{CO}$ and $\mathrm{H}_{2}$ is entrained to a series of equipment to get heavy oil ( $\mathrm{Cn} 10-\mathrm{Cn} 20)$, light oil $(\mathrm{Cn} 5-$ $\mathrm{Cn} 10)$, liquid petroleum gas (LPG, $\mathrm{Cn} 3-\mathrm{Cn} 4), \mathrm{CO}_{2}$ and high purity $\mathrm{H}_{2}\left(99.99 \%\right.$, mol\%). The pure $\mathrm{H}_{2}$, which is separated from the offgas by using the pressure swing adsorption (PSA) process operating at $2.0 \mathrm{MPa}$, is ready for syncrude upgrading. The final tail gas with low pressure is compressed and fed to the gas turbine system for the electricity generation. Figure 2 is a simple flow sheet of the FT synthesis process and the Tail gas process.

Under the action of the Fe based catalyst, the olefin/paraffin ratio of products from the slurry reactor was significantly greater than that from the fixed bed reactor, attributed at least in part to less secondary hydrogenation of olefins in the slurry reactor because of dilution [39]. A classic kinetics built on the industrial Fe based catalyst is applied for this paper [40]. The detailed hydrocarbon distributions is gotten from the data base which is depended on the tests of demonstration plant so the data is an empirical correlation to a certain extent. The hydrocarbon distributions is as following: $\mathrm{CH}_{4}, 4.4 \%(\mathrm{wt} \%), \mathrm{C}_{2} \mathrm{H}_{4}, 1.8 \%(\mathrm{wt} \%), \mathrm{C}_{2} \mathrm{H}_{6}$, $2.7 \%$ (wt $\%$ ), LPG, $11.2 \%$ (wt $\%$ ), light oil, 30.5\% (wt $\%$ ), heavy oil, $16.8 \%$ (wt \%), wax, $32.7 \%$ (wt $\%$ ). In addition, the overall $\mathrm{CO}$ conversion $\left(\mathrm{X}_{\mathrm{CO}}\right)$ is assumed to be $0.96, \mathrm{CO}_{2}$ selectivity $\left(\mathrm{S}_{\mathrm{CO} 2}\right)$ is 0.21 . The other parameters such as temperature and pressures are shown in Fig. 2. The simulation proposes an empirical correlation for more detailed.

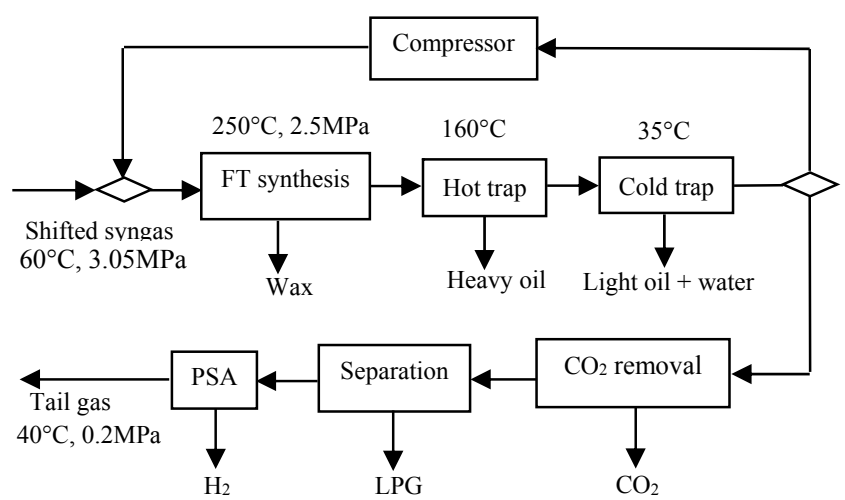

Figure 2. The simple diagram of FT synthesis and tail gas process

\section{F. Upgrading Process}

The olefins and oxygenated components in the syncrude are all converted into saturated paraffines in hydrogenation reactors. These paraffins with large molecular weight are further cracked into hydrocarbons with short chain length which fall into the range of the diesel fuels or naphtha. In the distilling tower, the different products are separated according to their different boiling point. The dry gas (including unreacted $\mathrm{CO}$, methane, ethane, excessive $\mathrm{H}_{2}$ and traces of other components) generated in the course of upgrade processing is also sent to the gas turbine for electricity generation. As the mass flow rate of feedstock (syncrude) is $1 \mathrm{~kg} / \mathrm{hr}$, the relative mass flow rates of the main products are $0.25 \mathrm{~kg} / \mathrm{hr}$ (naphtha), $0.72 \mathrm{~kg} / \mathrm{hr}$ (diesel). The dry gas of $0.03 \mathrm{~kg} / \mathrm{hr}$ (including unreacted $\mathrm{CO}$, methane, ethane, excessive $\mathrm{H}_{2}$ and traces of other components) generated in the course of upgrading processing is also sent to the gas turbine for electricity generation.

\section{G. $\mathrm{CO}_{2}$ Capture}

$\mathrm{CO}_{2}$ is removed in Rectisol process and the carbon removal unit of the FT synthesis process. The simulation shows most of $\mathrm{CO}_{2}$ (about $97.4 \%$ of all $\mathrm{CO}_{2}$ in the syngas) is removed in Rectisol process and the rest $\mathrm{CO}_{2}$ about $2.6 \%$ is removed in the carbon removal unit. As a result, the content of $\mathrm{CO}_{2}$ in FT-offgas is maintained about $1 \%(\mathrm{~mol} \%)$. The $\mathrm{CO}_{2}$-rich solution is sent to the regenerator where $\mathrm{CO}_{2}$ is released and the regenerated solution is recycled to the entrance of absorbers.

\section{H. Combined Cycle Process}

The fuel gas is composed of tail gas from PSA and the dry gas from upgrade section. In addition, the net output steams from gasification-FT-liquid process are sent to the heat recovery steam generator (HRSG), where the superheated steam is generated. Then the superheated steam is sent to the steam turbine for electricity production. In Fig. 3, LP means low pressure ranging from 0.1 to $1.5 \mathrm{MPa}$ and MP means middle pressure ranging from 2.5 to $3.5 \mathrm{MPa}$.

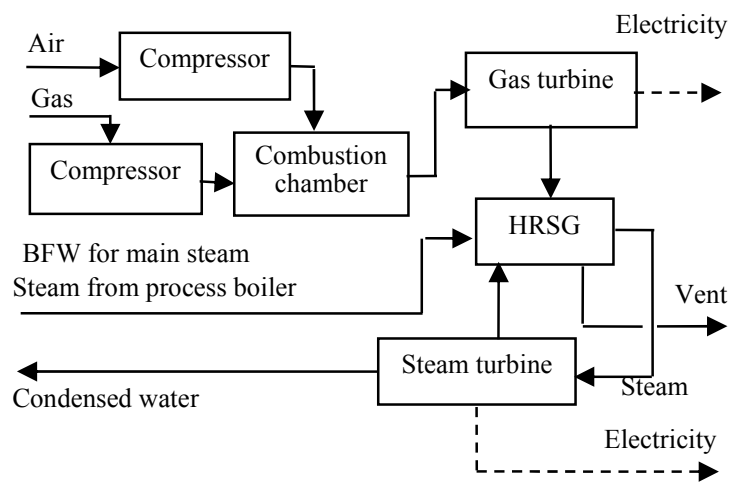

Figure 3. The schematic flow diagram of combined cycle process

The combusting chamber is simulated by an RGibbs model while the turbine is simulated by a MCompr model in Aspen Plus. The key data used in modeling are as follows: air temperature $=15^{\circ} \mathrm{C}$, air flow rate $=623.7 \mathrm{~kg} / \mathrm{s}$, pressure ratio $=15.4$, turbine inlet temperature $\left(\right.$ TIT) $=1327{ }^{\circ} \mathrm{C}$, turbine outlet temperature $(\mathrm{TOT})=609.4{ }^{\circ} \mathrm{C}$, gas turbine isentropic efficiency $=89.5 \%$, air compressor isentropic efficiency $=87.5 \%$.

\section{RESULT AND DISCUSSION}

The detailed material balance with electricity generation is shown in Table 3 .

It can be seen from Table 3 that Case 1 (based on Shell gasification) and Case 2 (based on GSP gasification) have the similar synfuels yields, which are obviously higher than 
those of Case 3 (based on GE gasification). This is because the quantity of the effective components of $\mathrm{CO}$ and $\mathrm{H}_{2}$ are similar in raw syngas of Case 1 and Case 2. And they are $10 \%$ higher than those from Case 3 . As to generating capacity of power in the three cases, they are similar when they are generated from gas turbine because FT synthesis processes of the three design options are the same and then combustible components and flow are similar in the tail gas. However, different gasification processes make the steam output quite different, which makes the generating capacity of the steam turbine significantly different. The generating capacity of the byproduct steam of the GSP in Case 2 is remarkably lower than those of the other two systems. Since the synfuels are the aimed products and electricity is secondary, valuable syngas is firstly used in the production of the FT liquids. The lower energy of tail gas results in generating capacity is not sufficient enough to meet the electricity consumption of the system itself. It is necessary to purchase electricity properly.

Case 1 has the highest thermal efficiency, and Case 2 is secondary and Case 3 has the minimum. Compared gasification processes of Case 1 and Case 2, the sensible heat of the former is fully utilized to produce $5.2 \mathrm{MPa}$ steam which is used for more electricity generation to improve the overall efficiency. The water chilling process of the GSP gasification process in Case 2 makes the water content increase to meet the demand of WGS reaction without the external vapor injection. But the gasifying sensible heat loss brings more disadvantages to the overall efficiency. Compared Case 3 with Case 2, the thermal efficiency of the former is lower. This is because GE gasification has lower cold gas efficiency than GSP gasification.

The results also indicate what contributions the cases make to the environment. There are two decarburization segments in the systems. Most $\mathrm{CO}_{2}$ is generated from the water-gas shift reaction and is captured in Rectisol process. A small amount of $\mathrm{CO}_{2}$ comes from $\mathrm{FT}$ synthesis process, where WGS reaction takes place on Fe based catalysts. It is shown in Table 4, the captured $\mathrm{CO}_{2}$ in three cases are $1707.4 \mathrm{t} / \mathrm{hr}, 1706.5 \mathrm{t} / \mathrm{hr}$ and $1644.3 \mathrm{t} / \mathrm{hr}$ respectively, and are equivalent to $58.7 \%, 58.6 \%$ and $59.5 \%$ of the ratio of Captured carbon elementals amount to the total carbon elementals respectively. $\mathrm{CO}_{2}$ emissions, which are mainly concentrated at the waste heat boiler exit of the combined cycle unit, are $71.6 \mathrm{t} / \mathrm{hr}, 71.5 \mathrm{t} / \mathrm{hr}$ and $70.1 \mathrm{t} / \mathrm{hr}$ respectively. Amount of carbon emission occupies 2.5\%, 2.5\% and 2.6\% of the total carbon in the three cases. However, considering the indirect emissions of the compression, the carbon emission is more than these amounts.

TABLE III. SIMULATION RESULTS OF THE INTEGRATED SYSTEMS BASED ON DIFFERENT GASIFICATION PROCESSES

\begin{tabular}{|c|c|c|c|}
\hline \multirow{2}{*}{ Items } & \multicolumn{3}{|c|}{ Input and output } \\
\cline { 2 - 4 } & Case 1 & Case 2 & Case 3 \\
\hline Feedstocks & & $-1000 / 81$ & $-1000 / 82$ \\
\hline $\mathrm{Coal}\left(\mathrm{t} / \mathrm{hr} /{ }^{\circ} \mathrm{C}\right)$ & $-1000 / 80$ & $-107 / 80$ & $-107 / 40$ \\
\hline Limestone $\left(\mathrm{t} / \mathrm{hr} /{ }^{\circ} \mathrm{C}\right)$ & $-107 / 80$ & & \\
\hline
\end{tabular}

\begin{tabular}{|c|c|c|c|}
\hline \multirow{2}{*}{ Items } & \multicolumn{3}{|c|}{ Input and output } \\
\hline & Case 1 & Case 2 & Case 3 \\
\hline $\begin{array}{c}\text { Oxygen for the } \\
\text { gasification }\left(\mathrm{t} / \mathrm{hr} /{ }^{\circ} \mathrm{C}\right)\end{array}$ & $-835.6 / 80$ & $-835.6 / 80$ & $-961.5 / 80$ \\
\hline $\begin{array}{l}\text { Water for the coal slurry } \\
\left(\mathrm{t} / \mathrm{hr} /{ }^{\circ} \mathrm{C}\right)\end{array}$ & - & - & $522 / 40$ \\
\hline $\begin{array}{c}\text { Steam for the } \\
\text { gasification }\left(\mathrm{t} / \mathrm{hr} /{ }^{\circ} \mathrm{C}\right)\end{array}$ & $-120 / 400$ & $-120 / 400$ & - \\
\hline $\begin{array}{c}\mathrm{CO}_{2} \text { for coal feeding } \\
\left(\mathrm{t} / \mathrm{hr} /{ }^{\circ} \mathrm{C}\right)\end{array}$ & $-157.2 / 80$ & $-157.2 / 80$ & - \\
\hline $\begin{array}{c}\text { Scrubbing water } \\
\left(\mathrm{t} / \mathrm{hr} /{ }^{\circ} \mathrm{C}\right)\end{array}$ & $-275 / 107$ & $-3720 / 141$ & $-2870 / 200$ \\
\hline $\begin{array}{l}\text { Steam into the WGS } \\
\text { reactor }\left(\mathrm{t} / \mathrm{hr} /{ }^{\circ} \mathrm{C}\right)\end{array}$ & $-275.8 / 270$ & 0 & 0 \\
\hline $\begin{array}{l}\text { Air for the Claus process } \\
\left(\mathrm{t} / \mathrm{hr} /{ }^{\circ} \mathrm{C}\right)\end{array}$ & $-5.2 / 25$ & $-5.1 / 25$ & $-5.1 / 25$ \\
\hline $\begin{array}{l}\text { Air for the gas turbine } \\
\left(\mathrm{t} / \mathrm{hr} /{ }^{\circ} \mathrm{C}\right)\end{array}$ & $-878.2 / 25$ & $-871.7 / 25$ & $-848.3 / 25$ \\
\hline \multicolumn{4}{|l|}{ Main products $\left(\mathrm{t} / \mathrm{hr} /{ }^{\circ} \mathrm{C}\right)$} \\
\hline diesel oil $/ \mathrm{t} / \mathrm{hr}\left(\mathrm{t} / \mathrm{hr} /{ }^{\circ} \mathrm{C}\right)$ & $205.2 / 272$ & $205.1 / 272$ & $183.8 / 272$ \\
\hline Naphtha $\left(\mathrm{t} / \mathrm{hr} /{ }^{\circ} \mathrm{C}\right)$ & $73.2 / 78$ & $73.2 / 78$ & $65.6 / 78$ \\
\hline $\operatorname{LPG}\left(\mathrm{t} / \mathrm{hr} /{ }^{\circ} \mathrm{C}\right)$ & $40.1 / 55$ & $40.1 / 55$ & $35.9 / 55$ \\
\hline $\begin{array}{c}\text { Sulfur recovered } \\
\left(\mathrm{t} / \mathrm{hr} /{ }^{\circ} \mathrm{C}\right)\end{array}$ & $2.4 / 244$ & $2.6 / 244$ & $2.4 / 244$ \\
\hline \multicolumn{4}{|l|}{ Waste products } \\
\hline Slag and $\operatorname{ash}\left(\mathrm{t} / \mathrm{hr} /{ }^{\circ} \mathrm{C}\right)$ & $225.7 / 1315$ & $225.7 / 1316$ & $233 / 709$ \\
\hline $\begin{array}{l}\mathrm{CO}_{2} \text { captured in the } \\
\text { Rectisol }\left(\mathrm{t} / \mathrm{hr} /{ }^{\circ} \mathrm{C}\right)\end{array}$ & $1381.5 / 17$ & $1380.8 / 17$ & $1358.2 / 17$ \\
\hline $\begin{array}{c}\mathrm{CO}_{2} \text { captured in the FTS } \\
\left(\mathrm{t} / \mathrm{hr} /{ }^{\circ} \mathrm{C}\right)\end{array}$ & $325.9 / 93$ & $325.7 / 93$ & $286.1 / 93$ \\
\hline $\mathrm{CO}_{2}$ mission $\left(\mathrm{t} / \mathrm{hr} /{ }^{\circ} \mathrm{C}\right)$ & $71.6 / 87$ & $71.5 / 87$ & $70.1 / 87$ \\
\hline $\begin{array}{l}\text { Tail gas of the Claus } \\
\text { process }\left(\mathrm{t} / \mathrm{hr} /{ }^{\circ} \mathrm{C}\right)\end{array}$ & $5.3 / 102$ & $5.3 / 103$ & $5.2 / 102$ \\
\hline $\begin{array}{l}\text { Waste water of the wet } \\
\text { scrubbing }\left(\mathrm{t} / \mathrm{hr} /{ }^{\circ} \mathrm{C}\right)\end{array}$ & $42.5 / 199$ & $2104.6 / 205$ & $1549.1 / 200$ \\
\hline $\begin{array}{l}\text { Waste water of the } \\
\text { Rectisol }\left(\mathrm{t} / \mathrm{hr} /{ }^{\circ} \mathrm{C}\right)\end{array}$ & $40.2 / 17$ & $1148.7 / 17$ & $1354.1 / 17$ \\
\hline $\begin{array}{l}\text { Waste water of the FTS } \\
\left(\mathrm{t} / \mathrm{hr} /{ }^{\circ} \mathrm{C}\right)\end{array}$ & $340.2 / 119$ & $339.9 / 119$ & $304.6 / 119$ \\
\hline $\begin{array}{c}\text { Vent of heating devices } \\
\left(\mathrm{t} / \mathrm{hr} /{ }^{\circ} \mathrm{C}\right)\end{array}$ & $59.6 / 156$ & $59.5 / 156$ & $53.3 / 155$ \\
\hline $\begin{array}{c}\text { Exhaust from the HRSG } \\
\left(\mathrm{t} / \mathrm{hr} /{ }^{\circ} \mathrm{C}\right)\end{array}$ & $911.9 / 59$ & $905.3 / 59$ & $882.2 / 59$ \\
\hline \multicolumn{4}{|l|}{ Electricity } \\
\hline $\begin{array}{l}\text { Generated by the gas } \\
\text { turbine (MW) }\end{array}$ & 166.6 & 165.5 & 161.2 \\
\hline $\begin{array}{c}\text { Generated by the steam } \\
\text { turbine (MW) }\end{array}$ & 300.1 & 68.5 & 254.3 \\
\hline $\begin{array}{l}\text { Sub-total of electricity } \\
(\mathrm{MW})\end{array}$ & -33 & -282.6 & -149.2 \\
\hline \multicolumn{4}{|l|}{ Utilities } \\
\hline Electricity (MW) & -499.8 & -516.7 & -564.8 \\
\hline $0.6 \mathrm{MPa}$ steam $\left(\mathrm{t} / \mathrm{hr} /{ }^{\circ} \mathrm{C}\right)$ & $-147.4 / 160$ & $-349.1 / 160$ & $-425.6 / 160$ \\
\hline $1.5 \mathrm{MPa}$ steam $\left(\mathrm{t} / \mathrm{hr} /{ }^{\circ} \mathrm{C}\right)$ & $1429.1 / 198$ & $1346.3 / 160$ & $1164.3 / 160$ \\
\hline 3.5 MPa steam $\left(\mathrm{t} / \mathrm{hr} /{ }^{\circ} \mathrm{C}\right)$ & $81.2 / 243$ & $96.9 / 243$ & \\
\hline 4.0MPa steam $\left(\mathrm{t} / \mathrm{hr} /{ }^{\circ} \mathrm{C}\right)$ & - & - & -0.0556 \\
\hline
\end{tabular}




\begin{tabular}{|l|c|c|c|}
\hline \multirow{2}{*}{ Items } & \multicolumn{3}{|c|}{ Input and output } \\
\cline { 2 - 4 } & Case 1 & Case 2 & Case 3 \\
\hline $5.2 \mathrm{MPa}$ steam $\left(\mathrm{t} / \mathrm{hr} /{ }^{\circ} \mathrm{C}\right)$ & $1244.7 / 270$ & - & - \\
\hline Water $\left(\mathrm{t} / \mathrm{hr} /{ }^{\circ} \mathrm{C}\right)$ & $63267.2 / 25$ & $77843.6 / 25$ & $84801.2 / 25$ \\
\hline cooling capacity $(\mathrm{MJ} / \mathrm{hr})$ & -222867.8 & -346943.2 & -363364.9 \\
\hline EFF $(\%)$ & 47.7 & 43.4 & 40.6 \\
\hline$\eta \mathrm{c}(\%)$ & 58.7 & 58.6 & 59.5 \\
\hline
\end{tabular}

Note: The negative numbers mean consumption and the positive numbers mean outputs.

With the LHV of the coal assumed as 100, the evaluation of coal energy transition among the sub-systems is further investigated. Seeing Fig. 4, the calculation begins with gasification and ends at the combined cycle. The results are listed in Table 4.

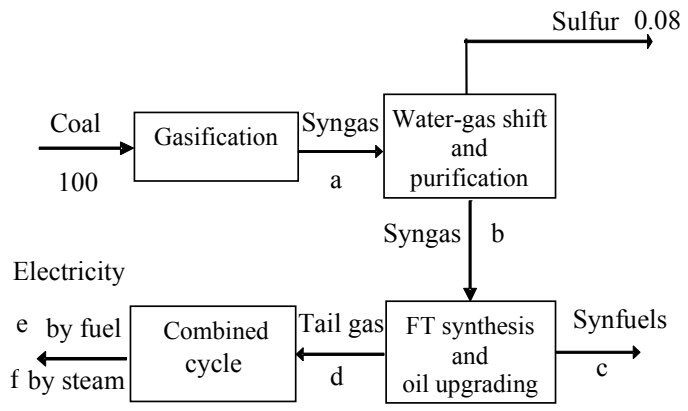

Figure 4. Energy utilization and distributing in the integrated systems

TABLE IV. ENERGY UTILIZATION AND DISTRIBUTION IN THE INTEGRATED SYSTEMS

\begin{tabular}{|c|c|c|c|c|c|c|}
\hline Cases & a & b & c & d & e & f \\
\hline Case 1 & 80.1 & 75.7 & 49.7 & 3.8 & 2.1 & 3.8 \\
\hline Case 2 & 80.0 & 75.7 & 49.7 & 3.8 & 2.1 & 0.9 \\
\hline Case3 & 70.1 & 67.6 & 44.6 & 3.7 & 2.0 & 3.5 \\
\hline
\end{tabular}

As can be seen from the results in Table 4, the systems based on Shell and GSP gasification processes have the similar energy distribution due to the similar syngas composition. However, steam generating capacity of the latter (f, in Table 4) significantly decrease. The reason is water chilling process sharply reduce the byproduct of the steam. In different gasification processes, energy loss of $2.6 \%-4.4 \%$ is caused by WGS process and the purification process. These two processes based on GE have lower energy consumption because higher ratio of $\mathrm{H}_{2} / \mathrm{CO}$ in the raw syngas makes $\mathrm{CO}$ conversion lower to meet the need of $\mathrm{H}_{2} / \mathrm{CO}=1.5$ (molar ratio) for FT synthesis process. To FT synthesis and upgrading process, the purified syngas is made as calculating basis, the same ratio of $\mathrm{H}_{2} / \mathrm{CO}$ and the same operating conditions (including temperature, pressure and recycle ratio, etc) result in similar energy efficiency. At the same time, similar tail gas composition and molar flow rate
(Based on the GE process, the molar flow rate of the tail gas accounted for about $97 \%$ of Shell and GSP) get similar gasfired power generation efficiency, up to about $56 \%$.

The energy distribution calculated by only considering coal energy transition limitedly reveals the main change trend. However, energy consumption of ASU is important to the overall systems. According to the results of calculation, electricity consumption of ASU is about $357 \mathrm{MW}-359 \mathrm{MW}$, which occupies $70 \%-72 \%$ of total electricity consumption. And the total electricity consumption equals to about 6\%-7\% of total coal energy input.

\section{CONCLUSION}

This paper investigates the processes based on commercially ready technology to convert coal to liquid fuels and waste energy utilization with $\mathrm{CO}_{2}$ sequestration. Three cases have been analyzed and the following conclusions can be drawn.

The integrated system based on Shell gasification process has the highest EFF of $47.7 \%$, the system based on GE gasification process has the lowest EFF of $40.6 \%$.

Shell and GSP processes have high cold gas efficiency. Compared with GSP, Shell gasification process can take full advantage of the gas sensible heat. Extra power generation can make the total efficiency increase nearly three percentage points. GE process produces steam of $4.0 \mathrm{MPa}$ for electricity generation and needs no steam injection for WGS. However, the coal slurry feed results in the lowest cold gas efficiency (approximately below 10\%), which makes this program has no advantages from the view of thermal efficiency.

The systems based on coal gasification imply a good chance for reducing greenhouse gas emission. The calculation results show that the captured $\mathrm{CO}_{2}$ in three cases are $1707.4 \mathrm{t} / \mathrm{hr}, 1706.5 \mathrm{t} / \mathrm{hr}$, and $1644.3 \mathrm{t} / \mathrm{hr}$, respectively. It is equivalent to recycle $58.7 \%, 58.6 \%$ and $59.5 \%$ of the total carbon content in the system. Since the indirect emissions of the compression are not considered, the actual captured carbon is lower than the calculated value.

\section{ACKNOWLEDGMENTS}

National Natural Science Foundation of China (21466029). Natural Science Foundation of Inner Mongolia (2014MS0210).

\section{REFERENCES}

[1] L. Zhu, Z. Zhang, J. Fan, and P. Jiang. "Polygeneration of hydrogen and power based on coal gasification integrated with a dual chemical looping process: Thermodynamic investigation," Computers and Chemical Engineering, vol. 84, Jan. 2016, pp. 302-312, doi:10.1016/j.compchemeng.2015.09.010.

[2] U. Sahoo, R. Kumar, P. C. Pant, and R. Chaudhury. "Scope and sustainability of hybrid solar-biomass power plant with cooling, desalination in polygeneration process in India, "Renewable and Sustainable Energy Reviews, vol. 51, Nov. 2015, pp. 304-316, doi:10.1016/j.rser.2015.06.004

[3] J. Y. Zhang, P. Liu, Z. Zhou, L. W. Ma, Z. Li, and W. D. Ni. "A mixed-integer nonlinear programming approach to the optimal design of heat network in a polygeneration energy," Applied Energy, vol. 114, Feb. 2014, pp. 146-154, doi:10.1016/j.apenergy.2013.09.057. 
[4] M. Rivarolo, A. Cuneo, A. Traverso, and A. F. Massardo. "Thermoeconomic optimization of the impact of renewable generators on poly-generation smart-grids including hot thermal storage," vol. 65, Jan.2013, pp. 75-83, doi:10.1016/j.enconman.2012.09.005

[5] L. M. Serra, M. Lozano, and J. Ramos. "Polygeneration and efficient use of natural resources," Energy, vol. 34, May 2009, pp.575-586, doi:10.1016/j.energy.2008.08.013.

[6] P. Gangadharan, A. Zanwar, K. L. Zheng, J. Gossage, and H. H. Lou. "Sustainability assessment of polygeneration processes based on syngas derived from coal and natural gas," Computers and Chemical Engineering, vol. 39, Apr. 2012, pp.105-117, doi:10.1016/j.compchemeng.2011.10.006.

[7] P. S. Chiesa, and C. T. Kreutz. "Co-production of hydrogen, electricity and $\mathrm{CO}_{2}$ from coal with commercially ready technology," International Journal of Hydrogen Energy, vol. 30, July 2005, pp. 747-767, doi: 10.1016 / j.ijhydene. 2004.08.002.

[8] J. Kuntal, and D. Sudipta. "Polygeneration using agricultural waste: Thermodynamic and economic feasibility study," Renewable Energy, vol. 74, Feb. 2015, pp. 648-660, doi:10.1016/j.renene.2014.08.078.

[9] M. J. A. Tijmensen, A. P. C. Faaij, and C. N. Hamelinck. "Exploration of the possibilities for production of Fischer Tropsch liquid and power via biomass gasification," Biomass and Bioenergy, vol. 23, .Aug. 2002, pp.129-152, doi:10.1016/S0961-9534(02)000375 .

[10] F. Normann, H. Thunman, and F. Johnsson. "Process analysis of an oxygen lean oxyfuel power plant with co-production of synthesis gas," Energy Convers. Manage, vol. 23, Aug. 2002, pp. 129-152, doi:10.1016 / S0961-9534 (02) 00037-5.

[11] E. Martelli, T. G. Kreutz, M.Gatti, P. Chiesa, and S. Consonni. "Numerical optimization of steam cycles and steam generators designs for coal to FT plants," Chemical Engineering Research and Design," vol. 91, Aug.2013, pp. 1467-1482, doi:10.1016/j.cherd.2013.02.026.

[12] X. An, B. S. Wu, H. J Wan, and T. Z. Li. "Comparative study of ironbased Fischer-Tropsch synthesis catalyst promoted with potassium or sodium," Catalysis Communications, vol. 8, Dec. 2007, pp. 19571962, doi:10.1016/j.catcom.2007.03.016.

[13] A. P. Steynberg, and M. E. Dry. Fischer-Tropsch Technology. 2rd ed., vol. 2, Amsterdam: Elsevier, 2004. pp. 182-192.

[14] Y. Yang, H. W. Xiang, and C. H. Zhang. "Structure and FischerTropsch performance of iron-manganese catalyst incorporated with $\mathrm{SiO}_{2}$," Applied Catalysis A: General, vol. 284, Apr. 2005, pp. 105122, doi:10.1016/j.apcata.2005.01.025.

[15] H. Schulz. "Short history and present trends of Fischer-Tropsch synthesis," Applied Catalysis A: General, vol. 186, Oct. 1999, pp. 312, doi:10.1016/S0926-860X(99)00160-X

[16] Z. Furinsky, and E. Li. "Comparison of Shell, Texaco, BGL and KRW gasifiers as part of IGCC plant computer simulations," Energy Conversion and Management, vol. 46, July 2005, pp. 1767-1779, doi:10.1016/j.enconman.2004.09.004.

[17] A. Thomas, P. I. Barton. "Combining coal gasification and natural gas reforming for efficient polygeneration" Fuel Processing Technology, vol. 92, Mar. 2011, pp. 639-655, doi:10.1016/j.fuproc.2010.11.023.

[18] T. Kolba, M. Aignerb, R. Kneerc, M. Müllerd, R. Webere, and N. Djordjevicf "Tackling the challenges in modelling entrained-flow gasification of low-grade feedstock," Journal of the Energy Institute. vol. 89, Nov. 2016, pp. 485-503, doi:10.1016/j.joei.2015.07.007.

[19] S. S. Seyitoglua, I. Dincerb, and A. Kilicarslana. "Energy and exergy analyses of hydrogen production by coal gasification," International Journal of Hydrogen Energy, vol. 84, Nov. 2016, pp. 444-458, doi:10.1016/j.ijhydene.2016.08.228.

[20] Z. G. Wen, Y. Yu, and J. Yan. "Best available techniques assessment for coal gasification to promote cleaner production based on the ELECTRE-II method," Journal of Cleaner Production,vol. 129, Aug. 2016, pp. 12-22, doi:10.1016/j.jclepro.2016.04.136.
[21] N. Mahinpey, and A. Gomez. "Review of gasification fundamentals and new findings: Reactors, feedstock, and kinetic studies," Chemical Engineering Science, vol. 148, July 2016, pp. 14-31, doi:10.1016/j.ces.2016.03.037.

[22] G. W. Yu, Y. Y. Xu, X. Hao, and Y. W. Li. "Process analysis for polygeneration of Fischer-Tropsch liquids and power with $\mathrm{CO}_{2}$ capture based on coal gasification," Fuel, vol. 89, May 2010, pp. 1070-1076, doi:10.1016/j.fuel.2010.01.016.

[23] X. D. Kong, W. M. Zhong, W. L. Du, and F Qian. "Three Stage Equilibrium Model for Coal Gasification in Entrained Flow Gasifiers Based on Aspen Plus ," Chinese Journal of Chemical Engineering, Vol. 21, Jan. 2013, pp. 79-84, doi:10.1016/S1004-9541(13)60444-9.

[24] Z. H. Zheng, and F. C. Wang. Coal gasification technologies. Fir. ed., vol. 1, Chemical Industry Press, 2005, pp. 55-57.

[25] F. C. Wang, X. Gong, H. F. Liu. "Process analysis and simulation of Shell pulverized coal gasification," Large Scale Nitrogenous, vol.35, Jan. 2012, pp. 381-384

[26] L. Yun, W. Noel, and C. L. David. "The origin of rhodium promotion of $\mathrm{Fe}_{3} \mathrm{O}_{4}-\mathrm{Cr}_{2} \mathrm{O}_{3}$ catalysts for the high-temperature water-gas shift reaction," Journal of Catalysis, vol. 239, Apr. 2006, pp. 227-236, doi:10.1016/j.jcat.2006.01.033.

[27] M. J. L. Ginés, N. Amadeo, and M. Laborde. "Activity and structuresensitivity of the water-gas shift reaction over $\mathrm{Cu}-\mathrm{Zn}$-Al mixed oxide catalysts," Applied Catalysis A: General, vol. 131, Oct. 1995, pp. 283-296, doi:10.1016/0926-860X(95)00146-8.

[28] J. Boon, V.Spallina, Y. Delft, and M. Sint. "Comparison of the efficiency of carbon dioxide capture by sorption-enhanced water-gas shift and palladium-based membranes for power and hydrogen production," International Journal of Greenhouse Gas Control, Vol. 50, July 2016, pp. 121-134, doi: 10.1016/j.ijggc.2016.04.033

[29] B. Wang. "Analysis and comparison for some kinds of methods of de-carbon," Chem. Fert. Des. Vol.45, May 2007, pp. 34-37.

[30] G. P. Shu. "Coal Liquefaction Technology," 2rd ed., vol. 1, Chemical Industry Press, 2013, pp. 65-68.

[31] W. Z. Kang. "Techno-economic comparison of rectisol and combination of NHD and Benfield," Fert. Ind., vol. 35 July 2009, pp. 18-23.

[32] S. S. Xu, D. L. Zhang, and Y. Q. Ren. "Large Scale Coal Liquefaction Technology," Fir. ed., vol. 1, Chem. Indus. Press, 2006, pp. 103-108.

[33] A. P. Steynberga, M.E. Dry, B. H. Davis, and B.B. Breman. "Chapter 2 - Fischer-Tropsch Reactors," Studies in Surface Science and Catalysis, vol. 152, 2004, pp. 64-195, doi:10.1016/S01672991(04)80459-2.

[34] M. E. Dry. "The production of hydrocarbons from coal," Endeavour, vol. 8, 1984, pp. 2-4, doi:10.1016/0160-9327(84)90121-2.

[35] L. Bai, H. W. Xiang, Y. W. Li, Y. Z. Han, and B. Zhong. "Slurry phase Fischer-Tropsch synthesis over manganese-promoted iron ultrafine particle catalyst," Fuel, vol. 81, July 2002, pp. 1577-1581, doi:10.1016/S0016-2361(02)00089-3.

[36] Y. Yang, H. W. Xiang, and R. Zhang. "A highly active and stable FeMn catalyst for slurry Fischer-Tropsch synthesis," Catal. Today, vol. 106, Oct. 2005, pp. 170-175, doi:10.1016/j.cattod.2005.07.127.

[37] B. Todic, L. Nowicki, N. Nikacevic, and D. B. Bukur. "FischerTropsch synthesis product selectivity over an industrial iron-based catalyst: Effect of process conditions," Catalysis Today, vol. 261, Mar. 2016, pp. 28-39 2007, doi:10.1016/j.cattod.2015.09.005.

[38] B. S. Wu, L. Bai, and H. W Xiang. "An active iron catalyst containing sulfur for Fischer-Tropsch synthesis," Fuel, vol. 83, Jan. 2004, pp. 205-212, 2004; 83: 205-212, doi:10.1016/S00162361(03)00253-9.

[39] F. G. Botes, J. W. Niemantsverdriet, and J. Loosdrecht. "A comparison of cobalt and iron based slurry phase Fischer-Tropsch synthesis," Catalysis Today, vol. 215, Oct. 2013, pp. 112-120, doi:10.1016/j.cattod.2013.01.013. 
[40] S.Mousavi, A. Zamaniyan, M. Irani, and M. Rashidzadeh "Generalized kinetic model for iron and cobalt based FischerTropsch synthesis catalysts: Review and model evaluation," Applied Catalysis A: General, vol. 506, Oct. 2015, pp. 57-66, doi:10.1016/j.apcata.2015.08.020. 